UDK 616.314.1

doi: $10.5937 /$ gads1449067T

\title{
TROŠENJE ZUBA
}

\author{
Ivan Tušek ${ }^{1}$, Jasmina Tušek ${ }^{2}$ \\ ${ }^{1}$ Univerzitet u Novom Sadu, Medicinski fakultet, Klinika za stomatologiju Vojvodine \\ ${ }^{2}$ Stomatološka ordinacija „Palmadent“" Novi Sad
}

\section{Sažetak}

Trošenje zuba predstavlja gubitak tvrdog zubnog tkiva nekarijesne etiologije i predstavlja čest klinički problem savremenog čoveka, čija je rasprostranjenost vrlo visoka i kreće se i do $97 \%$. Proces trošenja zuba se odvija kontinuirano tokom celog života i može usloviti različita oštećenja oblika, funkcije i vitaliteta zuba. Najčešće se gubitak tvrdih zubnih tkiva povezuje sa erozijom, atricijom abrazijom i abfrakcijom. U etiologiji lezija tvrdih zubnih tkiva dominantna su tri mehanizma: trenje (frikcija) koje je uzrokovano abrazijom egzogenog ili atricijom endogenog porekla, hemijsko rastvaranje tvrdih zubnih tkiva nastalo putem erozije i okluzalni stres nastao kompresijom, fleksijom i tenzijom koji dovodi do abfrakcije i mikrofraktura zuba.

Ključne reči: trošenje, erozija, abrazija, atricija, abfrakcija, prevencija, terapija.

\section{Uvod}

Analizirajući uzroke gubitka tvrdog zubnog tkiva kod čoveka, od praistorije do savremenog doba, mogu se konstatovati dva osnovna patološka mehanizma: karijes i trošenje zuba nekarijesne etiologije. Fenomen trošenja zuba definiše različite etiološke faktore koji deluju tokom celog života i mogu usloviti različita oštećenja oblika, funkcije i vitaliteta zuba (Badel i sar., 2007). Odavno je poznato da se stepen trošenja zuba povećava sa starenjem, a da za određene osobe ono može preći fiziološke granice, kada se moraju preduzeti određene terapijske mere kako bi se sprečila dalja oštećenja zuba. Najčešće se gubitak tvrdih zubnih tkiva povezuje sa erozijom, koja predstavlja progresivan gubitak zubne supstancije hemijskim rastvaranjem, atricijom koju prouzrokuju zubi antagonisti direktnim kontaktom i abrazijom, koja je izazvana drugim mehaničkim faktorima sem mastikacije (Grippo i sar., 2004). Vršene su različite klasifikacije trošenja zuba, koje su bazirane na etiologiji, kliničkoj slici, aktivnosti, progresiji i lokalizaciji promena na zubima, ali su danas priznata tri etiološka mehanizma koji mogu delovati izolovano ili sinergistički: trenje koje je uzrokovano abrazijom egzogenog ili atricijom endogenog porekla, hemijsko rastvaranje tvrdih zubnih tkiva nastalo putem erozije i okluzalni stres nastao kompresijom, fleksijom i tenzijom koji dovode do abfrakcije i mikrofraktura zuba. Od brojnih klasifikacija trošenja zuba, posebno je interesantna antropološka, koja je osnova Brokove skale procene intenziteta ove pojave kod drevnih civilizacija (Broca, 1879). Trošenje zubnih površina usled mikroskopske nesavršenosti zubnih površina se klinički najčešće manifestuje kao brusna faseta. Tribologija (d' Incau, 2012), kao interdisciplinarna nauka o mehanizmima trenja, trošenja i podmazivanja na ultrastrukturnom nivou, definisala je univerzalan model prema kome je etiopatogeneza trošenja zuba uslovljena: oboljenjima digestivnog trakta, nepravilnom oralnom higijenom, lošim navikama $u$ ishrani, temporomandibularnim (TM) poremećajima i jatrogeno. 


\section{Etiopatogenetski mehanizam trošenja zuba}

Analizirajući dominantne faktore u etiopatogenezi trošenja zuba može se konstatovati da zdravstveno stanje nije direktan etiološki faktor trošenja zuba, ali je zapažena viša prevalencija ove pojave kod psihijatrijskih bolesnika. Takođe, znatno je češća pojava atricije i erozije zuba kod osoba sa posebnim potrebama (Bell i sar., 2002). Erozija zuba najčešće nastaje kao posledica oboljenja digestivnog trakta, koja dovode do gastroezofagealnog refluksa želudačnog soka (GER), pri čemu oralna sredina postaje kiselija, što uzrokuje nekarijesnu demineralizaciju (trošenje) tvrdih zubnih tkiva. Oboljenja i/ili poremećaj funkcije pljuvačnih žlezda takođe mogu uticati na promenu količine i sastava pljuvačke, a samim tim i na brzinu nastanka i težinu kliničke slike trošenja zuba.Trošenje zuba u toku četkanja zubnom četkicom zavisi od njene tvrdoće, abrazivnih sastojaka zubne paste, kao i same tehnike četkanja zuba koja se upražnjava. Dugotrajno četkanje zuba horizontalnom tehnikom, prouzrokovaće karakteristične horizontalne uzure na vestibularnim površinama (Slika 1).
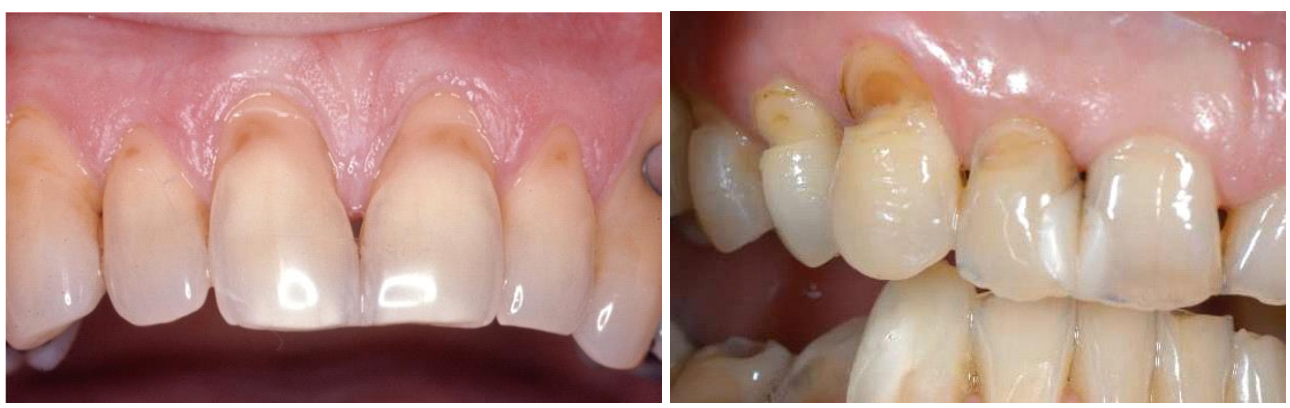

Slika 1. Trošenje cervikalnog područja gornjih sekutića nepravilnim četkanjem zuba.

Figure 1. Tooth wear of the cervical region of the upper incisors caused by improper brushing technique.

Savremena ishrana smanjila je mastikatorno trošenje zuba, ali je zahvaljujući hemijskom sastavu hrane, dovela do nastanka erozivnih promena na zubima. Učestala konzumacija citričnog voća, gaziranih sokova, zakišeljenog rafiniranof povrća, kao i način njihove upotrebe (dugo zadržavanje u ustima), takođe pogoduje nastanku erozivnog trošenja gleđi zuba. Nepravilne oralne navike, običaji i ponašanja mogu uzrokovati atipična trošenja zubnih površina i celih krunica zuba. Tako, grickanje noktiju, pušenje lule ili stalno držanje različitih predmeta između zuba kod određenih profesija (obućari, krojači, građevinski radnici i dr.) mogu prouzrokovati specifične oblike trošenja zuba. U tim slučajevima, osim pozitivnih anamnestičkih podataka u prilog postavljanju dijagnoze ide i činjenica da antagonističke fasete odgovaraju obliku korišćenog stranog predmeta ili alata. Dentalna erozija nastala zbog kiselih isparenja $\left(\mathrm{HCl}, \mathrm{H}_{2} \mathrm{SO}_{4}\right)$ kod radnika u hemijskoj industriji, pri elektrolitičkim procesima, i u fabrikama akumulatora može biti slična erozivnim promenama koje su izazvane lošim prehrambenim navikama. Ipak, u savremenom svetu, jedan od sve učestalijih etioloških faktora trošenja zuba je povećana bruksistička aktivnost.

Bruksizam je nesvrsishodna, parafunkcionalna i prekomerna aktivnost mišića žvakača, koja se manifestuje u vidu stiskanja i/ili škripanja zubima. Prekomerna i česta noćna bruksistična aktivnost, za razliku od fiziološke mišićne aktivnosti tokom sna, ubrzano i nefiziološki troši zubne površine. Dnevni bruksizam ili bruksomanija je teži oblik abnormalne mišićne aktivnosti, koji se klinički manifestuje u toku dana. U multifaktorskoj etiologiji bruksizma razlikuju se: periferni (morfološki) i centralni (psihološki) etiološki faktori. Iznenadno buđenje u toku spavanja ili promena dubine sna dovodi do generalizovanih promena aktivnosti $u$ 
organizmu: ubrzan rad srca, promena ritma disanja, mišićna hiperaktivnost uključujući i bruksizam (Basić V, 2004). Promene u sastavu centralnih neurotransmitera u nigrostrijatnoj formaciji mogu uzrokovati opisan poremećaj mišićne aktivnosti, a samim tim i pojavu bruksističke aktivnosti. Farmakološka terapija, takođe, može indukovati povećanje tonusa mastikatornih mišića i inicirati pojavu bruksizma. Tako lekovi kao što su: L-dopa, neuroleptici, amfetamin, nikotin, pa i alkohol, mogu biti etiološka podloga za razvoj bruksizma, što se objašnjava njihovim dejstvom preko dopaminskog sistema. Poremećaj ponašanja i afektivni psihološki faktori (anksioznost), mogu zajedno sa emocionalnim stresom prouzrokovati bruksističnu aktivnost, pri čemu su stres i emocionalni faktori primarni uzroci, koji uzrokujući parafunkcije, pokreću složene mehanizme oslobađanja od psihičke tenzije što rezultira pojavom bruksizma. Da malokluzije nisu primarni etiološki faktor trošenja zuba, potvrđuju i osobe kod kojih se javlja bruksizam, a kod kojih postoje pravilni okluzalni odnosi, i obrnuto, nema ga u slučajevima izuzetno narušenih okluzalnih odnosa (Rose, 2009). Bruksizam se pojavljuje u dva osnovna oblika:

a) horizontalni oblik (škripanje zubima), kada su prisutni ekstremni klizni pokreti levodesno, napred-nazad, te nastaje ozbiljno trošenje incizalnih ivica prednjih i kvržica bočnih zuba i

b) vertikalni oblik (stiskanje zuba), pri kome su prisutni minimalni pokreti zuba u okluziji (1-2 mm), pri čemu se troše lingvalne površine gornjih i antagonističke labijalne površine donjih prednjih zuba, pri čemu se dužina obe grupe zuba ne menja.

Broj i trajanje bruksističkih faza znatno varira ne samo između ispitanika nego i kod jedne iste osobe i traje od nekoliko sekundi do 40 minuta. U zavisnosti od pola, godina i mastikatornog tipa pacijenta, sile koje se fiziološki javljaju u toku žvakanja iznose od $10 \mathrm{~N}$ do $20 \mathrm{~N}$, sa malim varijacijama zavisno od vrste zuba (incizivi, molari). Za razliku od navedenih vrednosti kod osoba sa bruksomanijom trajanje bruksističkih faza je znatno duže i iznosi i do tri časa u toku dana, a intenzitet mastikatornih sila je i do 100 puta veći od fiziološkog (1000 N). Dijagnoza bruksizma postavlja se na osnovu: anamneze (heteroanamneze), stomatološkog pregleda (morfološke promene na okluzalnim-incizalnim površinama zuba, frakture krunica i/ili ispuna i dr. (Slika 2), analize okluzalnih odnosa, osetljivosti maseteričnih mišića i TM zglobova i dr.), kao i dodatnih dijagnostičkih pretraga.
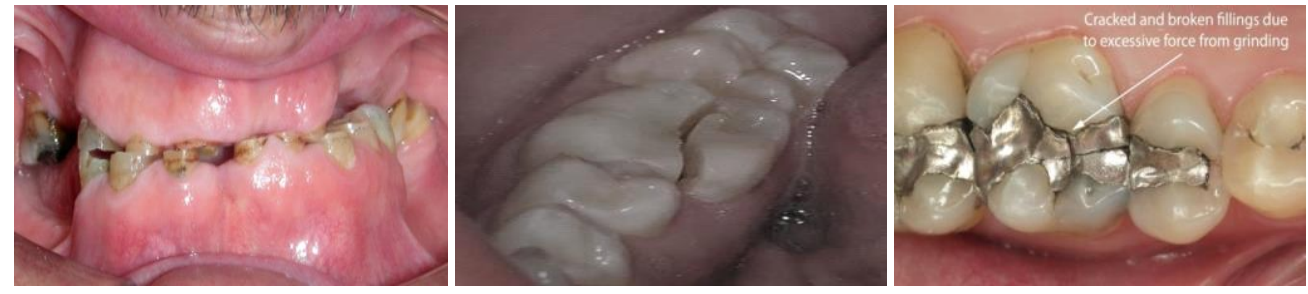

Slika 2. Intenzivne sile u toku bruksizma uzrokovale su ekstenzivno trošenje, frakture krunica i ispuna.

Figure 2. The intense force during bruxism have caused extensive wear, fractured crowns and fillings.

U kliničkoj slici dominiraju: ritmične kontrakcije i bol u mastikatornim mišićima, dnevnonoćno škrgutanje zubima, jutarnja glavobolja, otečeni i/ili bolni TM zglobovi, hroničan facijalni bol, frakturirani zubi i zubni ispuni kao i povređene desni. Registracija bruksističke aktivnosti se može obaviti u kućnim uslovima pomoću „bajt strip” minijaturnog elektromiografskog aparata, koji se postavlja na kožu maseterične regije u toku spavanja. Oznaka na displeju aparata pokazuje broj i trajanje bruksističkih epizoda u toku opservacionog perioda: $\mathrm{L}=$ nema bruksističke aktivnosti, 1 = prisutan je umeren bruksizam (30-60 bruksističkih epizoda), 2 = postoji 
srednje izražen bruksizam (61-100 bruksističkih epizoda) ili 3 = postoji jak bruksizam (više od 100 bruksističkih epizoda u toku sna). Postoji tesna veza između trošenja zuba, TM i mišićnoskeletnih poremećaja (Pergamalian, 2003). Pretpostavka je da bruksizam može biti potencijalni faktor rizika za nastanak TM poremećaja. Takođe, važno je naglasiti da se prilikom protetske rehabilitacije često zaboravlja na tvrdoću stomatoloških materijala od kojih se izrađuju nadoknade zuba. Ukoliko je restauracijski materijal tvrđi od gleđi (porcelan), isključivo će se trošiti antagonističke (okluzalne, incizalne) površine zuba. Nekada je klinički vrlo teško razdvojiti granicu između fiziološkog i patološkog trošenja zubnih tkiva. S obzirom na etiološku multifaktorijalnost ove pojave, svakako treba istaći da tribološki mehanizmi mogu delovati sinergistički ili izolovano, pri čemu se njihovo dejstvo može pojačavati sa vremenom. Treba na vreme uočiti koji se mehanizmi habitualnog ili patološkog trošenja zuba mogu najlakše ukloniti, te koliko će ti uzročnici negativno delovati na planiran restaurativni tretman.

\section{Procena i klasifikacija trošenja zuba}

U zavisnosti od vrste trošenja zuba, procena se može vršiti na osnovu kliničkog pregleda, kvalitativnim i kvantitativnim merenjem količine kalcijuma koji je oslobođen u toku erozivnog ataka ili se mogu fotometrijski registrovati promene optičkih osobina i tvrdoće gleđi. Međutim, identifikacija i valorizacija promena površinskih karakteristika (hrapavost, neravnine, transparencija) gleđi, može se vrlo uspešno realizovati i primenom kvantitativne, svetlosno indukovane fluorescencije ili optičke koherentne tomografije (Wilder-Smith, 2009). Za klinička istraživanja, najjednostavniji je indeks trošenja zuba Smita i Knajta. Istraživanja Gripoa i saradnika (Grippoa i sar.) definisala su sledeće oblike trošenja zuba:

Abrazija zuba (abrasio dentium) nastaje frikcijom između zuba i egzogenog stranog tela. Najčešće je to protetska nadoknada, ali abraziju mogu prouzrokovati i loše navike. Ukoliko je trošenje izraženo na okluzalnim i/ili incizalnim površinama zbog frikcije sa bolusom hrane naziva se mastikatorna abrazija (Slika 3). Ona se, takođe, može javiti na vestibularnim i lingvalnim površinama zuba zbog odbijanja hrane od jezika, usana ili obraza u toku žvakanja, pri čemu njen učinak zavisi od: veličine, količine i tvrdoće abrazivnih čestica hrane, kao i tvrdoće zubne gleđi. Početna oštećenja ogledaju se u jedva primetnim neravninama na zubnim površinama, pri čemu se više troše slabije mineralizovane površine zuba. Kod ovog oblika trošenja, istrošene zubne površine nisu nikada u dodiru u toku ekskurzijskih kretnji mandibule i uvek su istrošene okluzalne i /ili incizalne površine zuba antagonista. Učinak trošenja zavisi od vrste ishrane, odnosno tvrdoće hrane (Barbour, 2006). Abraziju četkanjem zuba, pored nepravilne tehnike pranja, uzrokuju uglavnom zubne paste, pri čemu njihov abrazivni učinak zavisi od: veličine i količine abrazivnih zrnaca, $\mathrm{pH}$ vrednosti, puferskog kapaciteta i koncentracije fluorida u zubnoj pasti. Ukoliko sadrže fluoride, zubne paste smanjuju erozivnu demineralizaciju i abraziju erodiranih površina zuba.
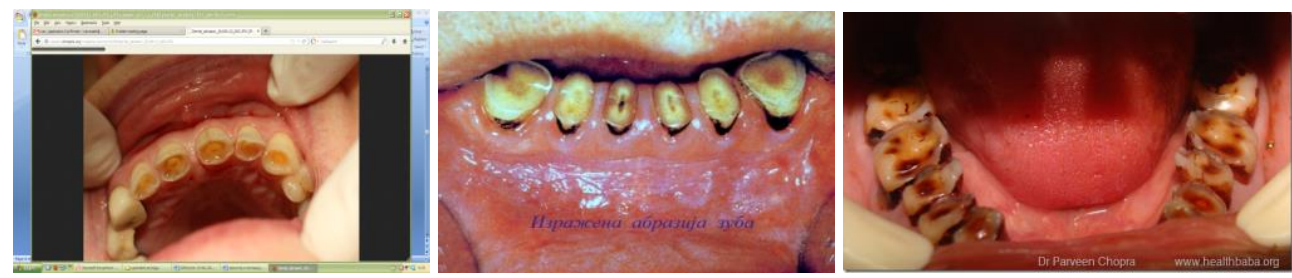

Slika 3. Uznapredovala abrazija u predelu sečivnih ivica frontalnih i okluzalnih površina bočnih zuba.

Figure 3. More progressing abrasion in the area of the frontal and occlusal surfaces of posterior teeth. 
Atricija zuba (attritio dentium) predstavlja trošenje zubnih tkiva u toku normalne mastikacije, frikcijom zuba o zub ili u toku parafunkcijskih kretnji mandibule (bruksizam) ali bez uticaja abrazivnog sredstva (Slika 4).
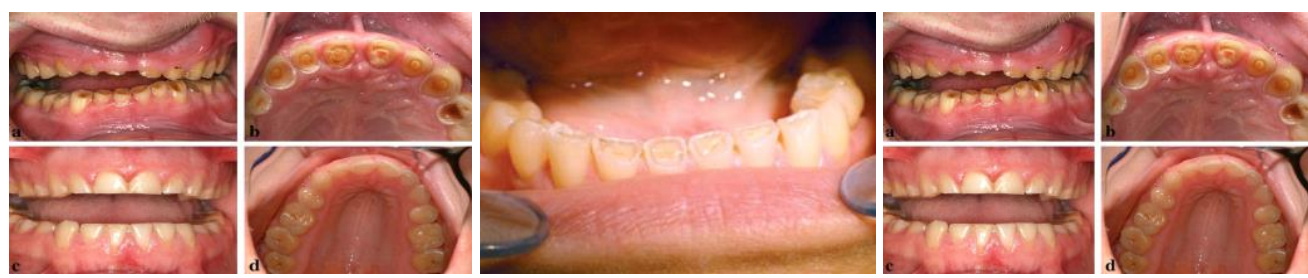

Slika 4. Atricija u predelu gornjih i donjih frontalnih zuba kod Prader-Vilijevog (Prader-Willi) sindroma.

Figure 4. Attrition of the upper and lower frontal teeth in patiens with Prader-Willi syndrome.

Proksimalna atricija, koja se javlja na kontaktnim područjima može prouzrokovati smanjenje zubnog luka i druge ortodontske poremećaje. Klinički, atriciju karakteriše pločast gubitak gleđi i/ili dentina sa asimetričnim ivicama koji nastaje u smeru pokretanja zuba na zub. Ekvivalentne fasete se uočavaju i na zubima suprotne vilice. Ukoliko su prisutni amalgamski ispuni, mogu se videti sjajne fasete na njima. Promene u morfologiji zuba su naročito izražene kod polifagičnog Prader-Vilijevog sindroma (Slika 4).

Erozija zuba (erosio dentium) je progresivni, ireverzibilni gubitak tvrdih zubnih tkiva koji je nastao delovanjem kiselina i /ili helacijom u ustima, ali bez učešća bakterija. Često je erozija prisutna kod osoba sa dobrom oralnom higijenom, kada je kombinovana sa mehaničkim trošenjem zuba (abrazija, atricija). Na razvoj erozije mogu uticati i biološki faktori, kao što su kvalitet zubne strukture, osobine pljuvačke, položaj zuba i anatomija mekih tkiva. Svakako da je pljuvačka najvažnija u smanjivanju trošenja gleđi i dentina u erozivno-abrazivnim atacima, pre svega zbog svog puferskog kapaciteta i stvaranja zaštitne pelikule na zubnim površinama. Kiseline koje dolaze u usnu šupljinu, egzogeno ili endogeno, mogu dovesti do različite kliničke slike erozija, u zavisnosti od: vremena izlaganja, mikrostrukture zuba, puferskog kapaciteta, količine pljuvačke i drugih faktora. Od endogenih faktora, najčešći uzrok erozija je GER ili povraćanje (gastritis, dijabetes, neurološki poremećaji, lekovi, trudnoća). Želudačna kiselina ima nizak pH, pa brzo dolazi do rastvaranja gleđi i dentina. Spontano povraćanje kod različitih poremećaja ishrane (anoreksija, bulimija, nervoza) mogu, takođe, usloviti pojavu erozije koja je vidljiva na palatinalnim površinama gornjih prednjih zuba, a u težim slučajevima i na bukalnim površinama bočnih zuba. Ovakav nalaz je tipičan zbog karakterističnog položaja glave pri povraćanju. Sličan objektivni nalaz zapa-

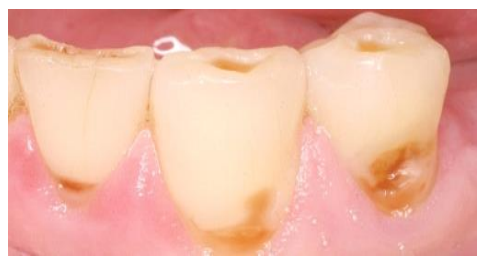

Slika 5. Umereno erozivno trošenje zuba u donjoj vilici. Figure 5. The moderate erosive wear on the lower jaw teeth. ža se i kod pacijenata sa GERom, ali je klinička slika blaža usled mešanja kiseline sa hranom (Bolfek, 2005). Stomato$\log$ je često prvi u prilici da postavi dijagnozu GER-a i da uputi bolesnika gastroenterologu (Holbrook, 2009). Žvakanje tableta vitamina $\mathrm{C}$, uzimanje aspirina, amfetamina, ekstazija i oralna aplikacija kokaina dovodi do cervikalne erozije na vestibularnim površinama gornjih frontalnih zuba i prvih premolara (Slika 5). 
Prilikom stomatološkog pregleda gleđ se čini tanja i prozirna, a gubitak je prisutan na okluzalnim površinama bočnih (zaobljavanje kvržica) i palatinalnim površinama prednjih zuba, pri čemu se konkaviteti javljaju i na cervikalnim područjima gornjih frontalnih zuba. Trošenje okluzalnih površina vremenom dovodi do nestanka kvržica i ekspozicije dentina.

Erozivni učinak kisele hrane i pića ne zavisi isključivo od njihove $\mathrm{pH}$ vrednosti, nego i od puferskog kapaciteta pljuvačke, frekvencije, dužine trajanja i načina unosa hrane i pića (Bassiouny, 2005). Učestala konzumacija alko-

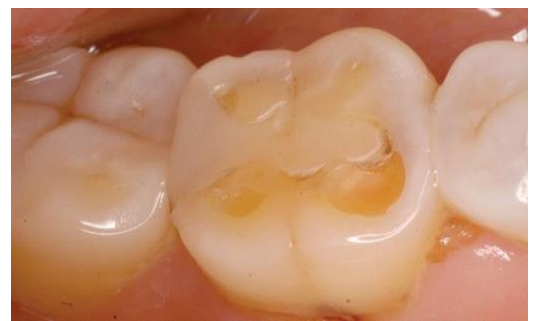

Slika 6. Mandibularni molari sa okluzalnim progresivnim erozivnim trošenjem.

Figure 6. Progressive erosive wear on the occlusal surfaceses of mandibular molars. hola, povezana sa hroničnim povraćanjem zbog gastritisa, takođe, pokazuje sliku erozije zuba. Ukoliko erozivni etiološki faktori nastave sa delovanjem, kvržice bočnih zuba se zaobljavaju, a na okluzalnim površinama se mogu zapaziti duboke kupaste lezije sa eksponiranim dentinom (Slika 6). Neposredno četkanje zuba nakon konzumacije kiselog pića svakako doprinosi erozivnom delovanju kiselina.

Abfrakcija zuba (abfractio dentium) predstavlja takvu vrstu trošenja zuba prilikom koje dolazi do fraktura gleđi u cervikalnom delu krunice zuba, kao posledica stresnog učinka okluzalnog opterećenja, pri čemu se funkcijske i parafunkcijske sile koncentrišu u predeo vrata zuba. Ovaj fenomen se objašnjava interakcijom okluzalnih sila, koje stvaraju fleksiju savijanje zuba u aksijalnom i paraaksijalnom smeru. Klinaste lezije na labijalnim površinama prednjih zuba su prvi put opisane još 1894. god. kao oštro ograničene promene u vidu „V” ureza na zdravoj gleđi, pa otuda potiče i naziv koji se održao do danas (Slika 7).
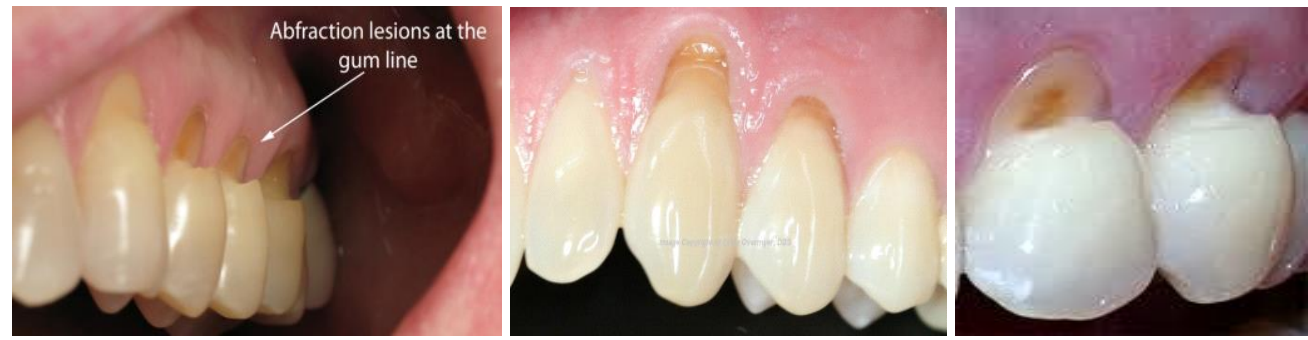

Slika 7. Klinaste lezije na labijalnim površinama vratova prednjih zuba.

Figure 7. Cuneiform lesions on the labial cervical surfaces of the anterior teeth.

Trošenje zuba abfrakcionog tipa je posebno izraženo na antagonističkim zubima, kod osoba sa bruksizmom i fiksnim protetskim nadoknadama (porcelanske krunice, mostovi).

U kliničkom radu je dosta teško diferencijalno-dijagnostički razdvojiti različite oblike patološkog od ,fiziološkog” oblika trošenja zuba, s obzirom na to da se ono sinergistički odvija u toku celog života dejstvom različitih etioloških faktora (Ceruti, 2006).

\section{Prevencija trošenja zuba}

S obzirom na to da je trošenje zuba multifaktorijalne prirode, preventivne mere se moraju primeniti, uzimajući u obzir hemijske, biološke faktore i ponašanje pacijenta (navike i dr.). Mnogobrojna istraživanja ukazuju da mehanički stres na erodiranim površinama uzrokuje uglavnom četkanje zuba četkicama sa čvrstim vlaknima, ali i atricija, trenje jezika ili abrazija 
okolnog mekog tkiva. Važno je naglasiti da električne i ručne četkice zbog različitog pritiska variraju u mogućnostima da uklone površinu demineralizovane gleđi i dentina (Tellefsen, 2011). Primarna prevencija obuhvata: preventivne mere vezane za faktore ponašanja, manju izloženost kiselinama, smanjivanje mehaničkog dejstva i preventivne mere povezane sa biološkim i hemijskim faktorima (Huysmans, 2011). Neophodno je izbegavati česte i obilne konzumacije kisele hrane i pića i upražnjavati pijenje na slamku, jer znatno smanjuje vreme kontakta zuba sa erozivnim pićem (voćni i gazirani sokovi). Svakako treba skrenuti pažnju da uzimanje droga, alkohola, kao i lakto-vegetarijanska ishrana može povećati rizik za nastanak dentalne erozije. Pacijente bi trebalo upozoravati da ne konzumiraju kisele međuobroke (hrana, napici), kako bi omogućili puferskim mehanizmima pljuvačke da očvrsnu erodiranu zubnu površinu (Tahmassebi, 2006). Savetuje se da pacijenti vode dnevnike ishrane u koje treba da evidentiraju učestalost, način unosa, duže zadržavanje kisele hrane i pića i dr. Obroke bi trebalo završiti hranom koja će pospešiti neutralisanje kiselih produkata u ustima (kačkavalj i mleko). Osobe koje rade u hemijskoj industriji, u procesima galvanizacije baterija i sl., trebalo bi obavezno da koriste zaštitnu opremu (maske za disanje, aspiratori). U profesije visokog rizika ubrajaju se i degustatori naročito belih vina (nizak pH), kao i aktivni plivači zbog učestalog kontakta zuba sa hlorisanom vodom u bazenima. U vezi sa tim preporučuje se primena neutralnih ili alkalnih vodica za ispiranje usta kao i korišćenje žvakaćih guma bez šećera, koje će povećati produkciju alkalnije pljuvačke. Poremećaji koji su povezani sa pojavom želudačne kiseline u ustima (povraćanje, GER, anoreksija, bulimija, ruminacija) svakako zahtevaju pored lokalne i kauzalnu terapiju ordinirajućeg lekara (opšti lekovi, psihoterapija). S obzirom na to da je pljuvačka najvažnija u smanjivanju trošenja tvrdih zubnih tkiva $u$ erozivno-abrazivnim atacima, preporučuje se uzimanje hrane i pića koji stimulišu lučenje veće količine alkalnije pljuvačke. Ovaj učinak se može povećati ispiranjem usta rastvorima koji sadrže kalcijum i fosfate, kao i konzumacijom mleka i tvrdih sireva. Takođe, tečnosti za ispiranje usta, gelovi i lakovi sa visokim sadržajem fluora, povećavaju otpornost na abraziju i smanjuju razvoj gleđne i dentinske erozije in vitro i in situ (Magalhaes, 2014). Alternativna preventivna metoda mogla bi uključiti i primenu sredstava za podmazivanje mesta trošenja zuba (prah $\mathrm{CaF}$, mešavina $\mathrm{CaF}$ i maslinovog ulja), kao i sredstava na bazi titanijum tetrafluorida $\left(\mathrm{TiF}_{4}\right)$. Istraživanja sa veštačkim zaslađivačima su takođe pokazala da ksilitol može stvarati komplekse sa kalcijumom, penetrirati u demineralizovanu gleđ i smanjiti difuziju i gubitak rastvorenog kalcijuma i fosfata iz erozivne lezije u pljuvačku. Istraživanja de- i remineralizacionih procesa u toku inicijalne karijesne lezije ukazala su na značaj povećane koncentracije kalcijuma $\left(\mathrm{Ca}^{++}\right)$u pljuvački i dentalnom biofilmu u prisustvu fluorida. Ovaj efekat $\mathrm{Ca}^{++}$mogao bi prevenirati nastanak i progresiju dentalne erozije, s obzirom na stvaranje depoa $\mathrm{CaF}_{2}$ na površini gleđi. Najjednostavniji način aplikacije svakako bi uključio četkanje zuba sa pastama koje su obogaćene kalcijumom. U vezi sa tim, istraživanja (Wegehaupt, 2010) su ukazala na protektivno delovanje paste sa kazein-kalcijum fosfatom na eroziju gleđi u in vitro uslovima. Nedavna istraživanja (Piekarz i sar. 2008) pokazuju da CPP-ACP odn. kazein fosfopeptid-amorfni kalcijum fosfat („Tooth Mousse”) snažno smanjuje eroziju gleđi koja je eksperimentalno uzrokovana limunskom kiselinom i kiselim sportskim napicima, te ga posebno preporučuju i kod atricijskog trošenja dentina. Utvrđeno je da CPP-ACP održava nivo zasićenosti kalcijuma i fosfata na površini zuba i predstavlja rezervu neutralnih jonskih parova koji inhibišu demineralizaciju i forsiraju stvaranje kristala hidroksiapatita u karijesnoj i nekarijesnoj leziji, odn. kod trošenja zuba. Činjenica da „Tooth Mousse”, povećava tvrdoću gleđi koja je erodovana sa koka-kolom, ukazuje da ovaj preparat aktivno učestvuje i u procesima remineralizacije. Odnedavno se na tržištu pojavila i pasta za zube koja pored CPP-ACP sadrži i fluoridne nanokomplekse, te je njena primena podjednako efikasna kako u kiseloj, tako i neutralnoj sredini, i može smanjiti eroziju uzrokovanu limunskom kiselinom, belim vinom, sportskim napicima, kao i erozivno trošenje i abraziju nastalu četkanjem zuba. Najnoviji preparat koji aktivno učestvuje u remineralizaciji tvrdih zubnih tkiva i smanjenju njihove 
osetljivosti na termičke i hemijske nadražaje je „ReminPro”, koji sadrži fluoride, hidroksiapatit (prirodan konstituens gleđi) i ksilitol (veštački zaslađivač). U savremenoj stomatološkoj praksi sve je veća primena i različitih vrsta lasera (dijodni, $\mathrm{CO}_{2}, \mathrm{Nd}$ :YAG, Ar) u prevenciji trošenja zuba. Konstatovano je da laserska terapija uzrokuje smanjenje karbonata na zubnoj površini i ubrzava tranformaciju hidroksi u fluorapatit u prisustvu fluorida. Rastvorena površina gleđi delovanjem lasera, uzrokuje rast gleđnih kristala, smanjujući interprizmatične prostore, a samim tim smanjuje difuziju kiselina tokom erozivnog ataka. Nedavno sprovedena petodnevna studija (Banda i sar. 2011) pokazala je da je primena lasera Nd:YAG $(0.5 \mathrm{~W}, 0.75 \mathrm{~W}$ i $1 \mathrm{~W}) \mathrm{u}$ in vitro uslovima u kombinaciji sa aplikacijom fluorida, značajno smanjila erozivno trošenje gleđi. Isti autori su istakli da je dentin tretiran laserom Nd:YAG, snage $0,6 \mathrm{~W}$ otporniji na kisele napitke (koka-kola, bezalkoholna gazirana pića, voćni sokovi). Naredna istraživanja svakako bi trebalo usmeriti ka inhibitorima matriks-metaloproteinaza (MMP), koji u oralnoj sredini katališu hidrolizu ekstracelularnog matriksa (ECM) u procesima razgradnje i remodelacije matriksa zuba. Aktivacija MMP-a je odgovorna za razgradnju kolagena, progresiju erozije, odnosno trošenje zuba. Najnovija istraživanja u vezi sa tim (Tjärdehan i sar. 2012) pokazala su da se latentni oblici $\mathrm{MMP}_{2}$ i $\mathrm{MMP}_{9}$ mogu aktivirati u kiseloj sredini koja prati eroziju zuba, te bi bilo zanimljivo u cilju prevencije trošenja zuba pronaći efikasne inhibitore MMP-a kod pacijenata sa visokim rizikom. Utvrđeno je da polifenoli zelenog čaja (epigalokatehin galat), kao i ekstrakti avokada, zrna soje i oleinska kiselina preveniraju trošenje zuba, jer poseduju snažno inhibitorno dejstvo na MMP. Zato se preporučuje ispiranje usta sa zelenim čajem, jer znatno smanjuje eroziju i abraziju zuba. Kao vrlo efikasan inhibitor MMP-a se pokazao oralni hemioterapeutik hlorheksidin (CHX), kada se primenjuje između erozivnih ataka kiselina u ustima, te se svakako preporučuje u prevenciji svih oblika trošenja zuba. Savremeni pristup prevencije bruksizma uključuje i „,biofidbek” tretman, oralne senzore, nociceptivne trigeminalne inhibitore - „stražare”, kinezi, krio i farmakoterapiju (Tušek, 2014). Od mehaničkih pomagala, u cilju prevencije oštećenja zuba, pacijentima se preporučuju fabrički ili individualni silikonski splintovi, tzv. štitnici koji se postavljaju na gornje ili na donje zube i onemogućavaju kontakt zuba obe vilice, a samim tim i trošenje zuba.

\section{Terapija trošenja zuba}

U zavisnosti od stepena trošenja zuba restaurativni postupak može uključiti adhezivno postavljanje kompozitnog ili glasjonomernog ispuna u područjima erozije, ili protetsku rehabilitaciju (Slika 8) u slučajevima jako destruisane denticije.

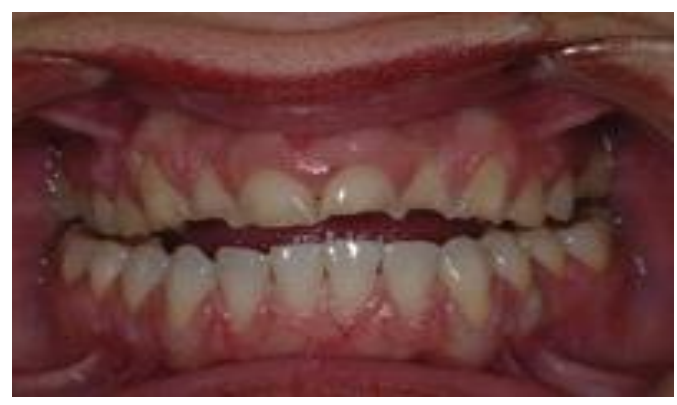

a

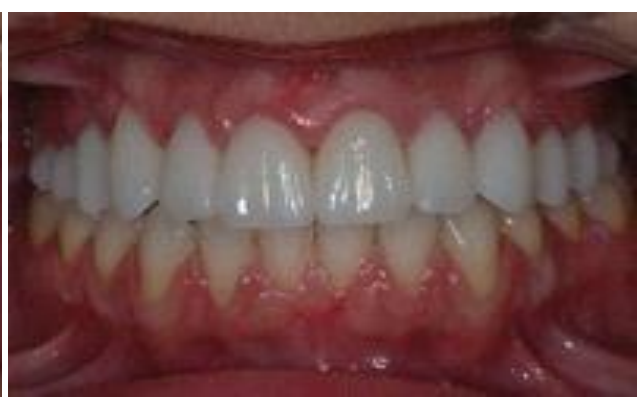

b

Slika 8. Progresivno trošenje zuba u gornjoj vilici: $\mathrm{a}$ - pre tretmana, $\mathrm{b}$ - nakon protetske rehabilitacije.

Figure 8. Progressive wear of teeth in the upper jaw: $a$-before treatment, $b$-after prosthetic rehabilitation. 


\section{Literatura}

Badel T, Keros J, Šegović S, Komar D. Klinički i tribološki pogled na trošenje zuba. Acta Stomatol Croat. 2007; 41(4): 355-366.

Grippo JO, Simring M et al. Attrition, abrasion and abfraction revisited. JADA. 2004; 135: 1109-1118.

Broca P. Instructions relatives à l' étude athropologique du systéme dentaire. Bull Soc Anthrop Paris 1879; 2(2): 128-163.

d' Incau E, Couture C, Maureille B. Human tooth wear in the past and the present: Tribological machanisms, scoring systems, dental and sceletal compensations. Archives of Oral Biology 2012; 57: 214-229.

Bell EJ, Kaidonis J, Townsend GC. Toth wear in children with Down syndrome. Aust Dent J. 2002; 47(1): 30-35.

Basić V, Mehulić K. Bruksizam - neriješen stomatološki problem. Acta Stomatol Croat. 2004; Vol. 38 (1): 87-91.

Rose JC, Roblee RD. Originis of dental crowding and malocclusions:an anthropological perspective. Compend Contin Educ Dent. 2009; 30(5): 292-300.

Pergamalian A, Rudy TE, Zaki HS, Greco CM. The association between wear facets, bruxism, and severity of facial pain in patients with temporomandibular disorders. J Prosthet Dent. 2003; 90(2): 194-200.

Wilder-Smith CH, Wilder-Smith P, et al. Quantification of dental erosions in patients with GERD using optical coherence tomography before and after double-blind, randomized treatment with esomeprazole or placebo. Am J Gastroenterol. 2009; 104(11): 2788-2795.

Barbour ME, Rees GD. The role of erosion, abrasion and attrition in tooth wear. J Clin Dent. 2006; 17(4): 88-93.

Bolfek I, Katunarić M et al. Gubitak tvrdog zubnog tkiva nekarijesne etiologije - abrazija, atricija, erozija i abfrakcija. Medix. 2005; 58(XI): 149-50.

Holbrook WP. Furuholm J, Gudmundsson K. et al. Gastric reflux is a significant causative factor of tooth erosion. J Dent Res. 2009;88(5): 422-6.

Bassiouny MA. Influence of drinking patterns of carbonated beverages on dental erosion. Gen Dent. 2005; 53(3): 205-210.

Ceruti P, Menicucci G, Mariani GD, Pittoni D, Gassino G. Non carious cervical lesions. A review. Minerva Stomatol. 2006; 55 (1-2): 43-57.

Tellefsen G, Liljeborg A, Johannsen A, Johannsen G. The role of the toothbrush in the abrasion process. Int J Dent Hygiene. 2011; 9: 284-290.

Huysmans MCDNJM, Chew HP, Ellwood RP. Clinical Studies of Dental Erosion and Erosive Wear. Car Res. 2011; 45 (Suppl 1): 60-68.

Tahmassebi JF, Duggal MS, Malik-Kotru G, Curzon ME. Soft drinks and dental health: a review of the current literature. J Dent. 2006; 34 (1): 2-11.

Magalhaes AC, Wiegand A, et al. Use dentifrices to prevent erosive tooth wear: harmful or helpfuul? Braz Oral Res. 2014; 28(Spec Iss 1): 1-6.

Wegehaupt $\mathrm{Fj}$, Attin T. The role of fluoride and casein phosphate/amorphous calcium phosphate in the prevention of erosive/abrasive wear in an in vitro model using hydrochloric acid. Caries Res 2010; 44: $358-363$.

Piekarz C, Ranjitkar S, Hunt D, Mclntyre J. An in vitro assessment ofthe role of Tooth Mousse in preventing wine erosion. Aust Dent J. 2008; 53: 22-25.

Banda NR,Vanaja Reddy G, Shashikiran ND. Evaluation of primary tooth enamel surface morphology and microhardness after Nd:YAG laser irradiation and APF gel treatment - an in vitro study. J Clin Pediatr Dent. 2011; 35: 377-382.

Tjäderhane L, Vered M, Pääkkönen V, at al. The expression and role of Lysyl oxidase (LOX) in dentinogenesis. Internat Endodont Jour. Article first published online: 28 nov 2012, DOI: 10.1111/iej.12031

Gajić M. Tušek I, Lalić M,Tušek J. Preventivna stomatologija, Grafos International, Pančevo, 2014. 


\title{
TOOTH WEAR
}

\author{
Ivan Tušek, Jasmina Tušek
}

\section{Summary}

Tooth wear is the loss of dental hard tissue that was not caused by decay and represents a common clinical problem of modern man. In the etiology of dental hard tissue lesions there are three dominant mechanisms that may act synergistically or separately:friction (friction), which is caused by abrasion of exogenous, or attrition of endogenous origin, chemical dissolution of dental hard tissues caused by erosion, occlusal stress created by compression and flexion and tension that leads to tooth abfraction and microfracture. Wear of tooth surfaces due to the presence of microscopic imperfections of tooth surfaces is clinically manifested as sanding veneers. Tribology, as an interdisciplinary study of the mechanisms of friction, wear and lubrication at the ultrastructural level, has defined a universal model according to which the etiopathogenesis of tooth wear is caused by the following factors: health and diseases of the digestive tract, oral hygiene, eating habits, poor oral habits, bruxism, temporomandibular disorders and iatrogenic factors. Attrition and dental erosion are much more common in children with special needs (Down syndrome). Erosion of teeth usually results from diseases of the digestive tract that lead to gastroesophageal reflux (GER) of gastric juice $(\mathrm{HCl})$. There are two basic approaches to the assessment of the degree of wear and dental erosion. Depending on the type of wear (erosion, attrition, abfraction), the amount of calcium that was realised during the erosive attack could be determined qualitatively and quantitatively, or changes in optical properties and hardness of enamel could be recorded, too. Abrasion of teeth (abrasio dentium) is the loss of dental hard tissue caused by friction between the teeth and exogenous foreign substance. It is most commonly provoked by prosthetic dentures and bad habits, while its effect depends on the size of abrasive particles and their amount, abrasive particle hardness and hardness of tooth surfaces. Attrition of teeth (attritio dentium) represents teeth wear during mastication, friction on the tooth or teeth during parafunctional mandibular movements (bruxism), but without the abrasive effect. Dental erosion (erosio dentium) or corrosive wear is a progressive, irreversible loss of dental hard tissue resulting from the effect of acids and /or chelation in the mouth, but without the participation of bacteria. Acids, of either exogenous or endogenous origin (peptic ulcer, gastritis, or bulimia, anoreksia nervosa), that come into the mouth can lead to different clinical manifestations of erosion depending on the time of exposure, the microstructure of teeth, buffering capacity, the amount of saliva and other factors. The changes are visible on the palatal surfaces of upper anterior teeth and, in severe cases, the lingual surfaces of posterior teeth. Occupational dental erosion occurs during exposure to industrial gases that contain hydrochloric or sulfuric acids, as well as the acids used in galvanizing and manufacture of battery and weapons. Due to the multifactorial nature of erosive tooth wear preventive measures must be applied taking into account chemical and biological factors as well as the patient's behavior associated with the etiology and pathogenesis of erosion. It is recommended to consume food and drinks that stimulate the secretion of large amounts of saliva base; to use neutral or alkaline mouthwash, and to chew sugar-free gum; to apply adequate oral hygiene (soft brushes, non-abrasive tooth paste, proper washing technique) and not to consume aciding food and carbonated soft drinks and fizzy drinks in a great amount and frequently. It is necessary to apply preparations with high content of fluoride, and lubricant of tooth wear (powder $\mathrm{CaF}, \mathrm{CaF}$ mixture and olive oil), and asset-based titanium tetrafluoride and casein-calcium phosphate. Commercial tooth paste that contains CPP-ACP (casein phosphopeptide-amorphous calcium phosphate) and calcium phosphate nanocomplexes is now available. Its use is equally effective in acidic and in neutral media. In the prevention of tooth wear, lasers (CO2, Nd:YAG) and enzymes (matrix metalloproteinases) are being used more frequently in modern dental practice. Depending on the degree of tooth wear, the restorative procedure, may consist of bonded composites, or glass ionomer cement restorations of tooth wear, as well as complete reconstruction of the crown (prosthetic rehabilitation) in cases of severely destroyed dentition.

Key words: tooth wear, erosion, abrasion, attrition, abfraction, prevention, therapy. 